\title{
First Report of Bacterial Soft Rot of Aloe vera (Aloe barbadensis ) Caused by Pectobacterium chrysanthemi in Bangladesh
}

\section{Pervez $Z^{*}$, Alam MS and Islam MS}

Department of Plant Pathology, Patuakhali Science and Technology University, Dumki, Patuakhali, Bangladesh

"Corresponding author: Zehad Pervez, Department of Plant Pathology, Patuakhali Science and Technology University, Dumki, Patuakhali, Bangladesh, Tel: 01921818281; E-mail: zehadpervez@yahoo.com

Rec date: November 29, 2016; Acc date: November 30, 2016; Pub date: November 30, 2016

Copyright: @ 2016 Pervez Z, et al. This is an open-access article distributed under the terms of the creative commons attribution license, which permits unrestricted use, distribution, and reproduction in any medium, provided the original author and source are credited.

Citation: Pervez Z, Alam MS, Islam MS (2016) First Report of Bacterial Soft Rot of Aloe vera (Aloe barbadensis) Caused by Pectobacterium chrysanthemi in Bangladesh. J Plant Pathol Microbiol 7: 1000e110. doi:10.4172/2157-7471.1000e110

\section{Editorial}

Bacterial soft rot of Aloe vera caused by Pectobacterium chrysanthemi was observed for the first time in June, 2016 at the field of Germplasm Centre of Patuakhali Science and Technology University, Bangladesh. This disease was first reported from the Caribbean island of Aruba [1] and Korea [2]. However, this is the first report of the disease from Bangladesh. In India this disease was observed for the first time in 2000, at the National Research Centre for Medicinal and Aromatic Plants, India.

A new serious outbreak of the disease was observed during the rainy season in 2016 on two-year-old plants of Aloe vera at the Germplasm Centre of Patuakhali Science and Technology University, Bangladesh. Initial symptom of the disease started as water soaked lesions at the base of the leaves. The rotting progressed very fast and the whole plant died within four to five days. As rotting spreads through the insides of the plant, the leaves turn mushy and collapse. An identifying symptom developed as the rotting progressed, the leaf epidermis bulged out due to gas formation and the leaf content was converted to a slimy mass (Figure 1).

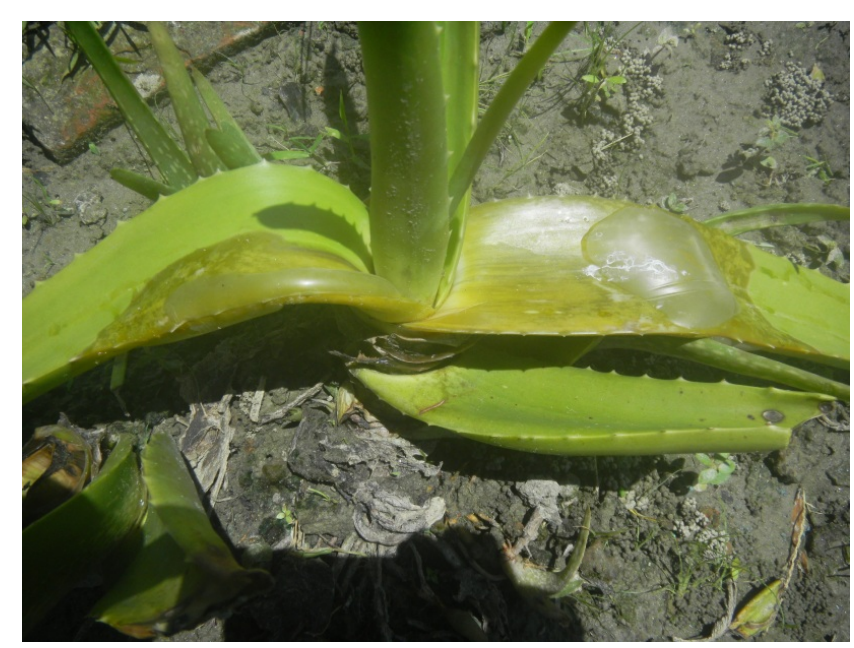

Figure 1: Leaf epidermis bulged out symptom.

Pathogenicity assays were performed on healthy Aloe vera plants grown in pots. Suspensions $\left(10^{8} \mathrm{cfu} / \mathrm{ml}\right)$ of a single isolate of
Pectobacterium chrysanthemi were injected into the base of the plant leaf using a hypodermic needle. After six days, the rotting and bulged out symptoms (Figure 2) were appeared in inoculated pot plants as symptoms found in field plants. This is the first report of bacterial soft rot by Pectobacterium chrysanthemi in Bangladesh [3].

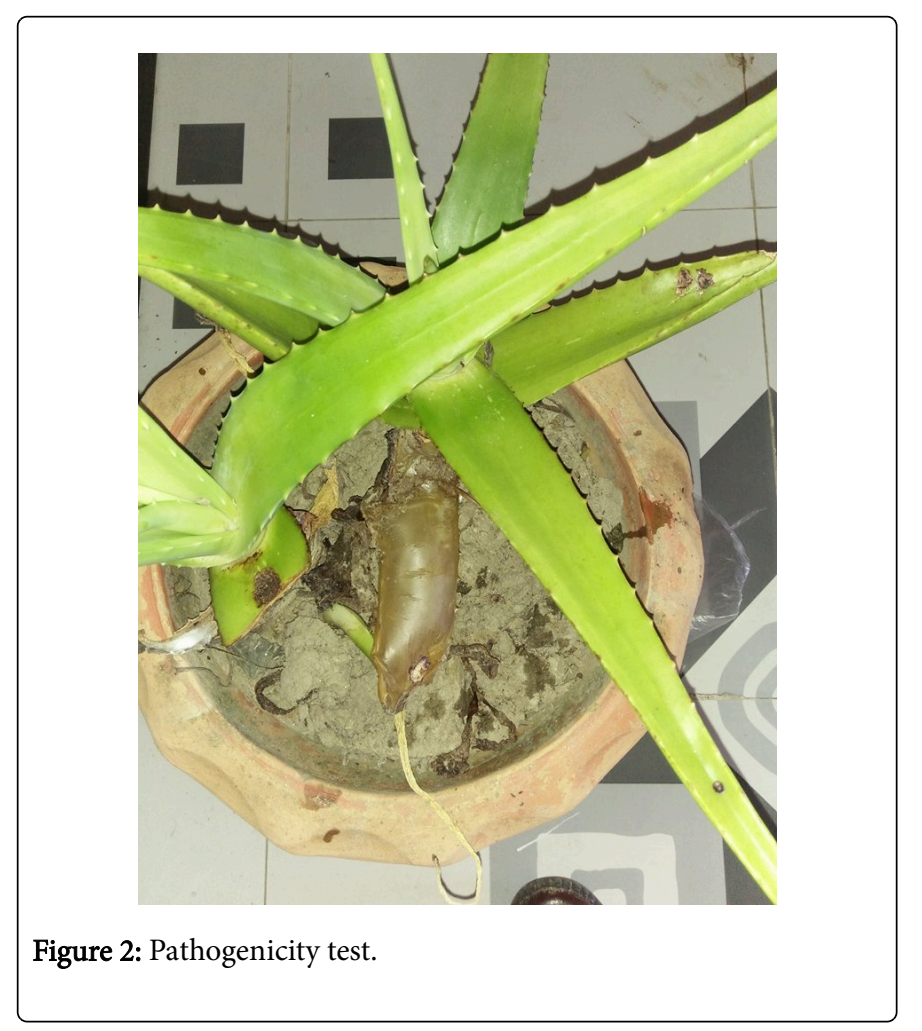

\section{References}

1. Laat PCA de, Verhoeven JTW, Janse JD (1994) Bacterial leaf rot of Aloe vera L., caused by Erwinia chrysanthemi biovar 3. Eur J Plant Pathol 100: $81-84$.

2. Jin KS, Lee SW, Kim JJ, Ryu HY (1994) Identification of bacterial isolates obtained from diseased orchid and aloe plants caused by Erwinia chrysanthemi. RDA J Agri Sci Crop Prot 36: 301-306.

3. Mandal K, Maiti S (2005) Bacterial soft rot of aloe caused by Pectobacterium chrysanthemi: A new report from India. New Dis Rep 11: 1. 